\title{
Residiv og overlevelse etter brystbevarende behandling av brystkreft
}

\author{
Sammendrag \\ Bakgrunn. Formålet med denne retro- \\ spektive studien var å undersøke lokal \\ sykdomskontroll og overlevelse for \\ pasienter med tidlig brystkreft som har \\ gjennomgått brystbevarende kirurgi \\ med etterfølgende strålebehandling \\ ved én enkelt institusjon.
}

Materiale og metode. Vi inkluderte alle kvinner med tidlig brystkreft som i tiden mellom 14. juni 1999 og 8. mars 2002 gjennomgikk postoperativ strålebehandling mot hele brystet ved vårt sykehus. Det ble gjennomført CTbasert doseberegning for alle pasienter

Resultater. Vi registrerte 222 kvinner som i den aktuelle perioden gjennomgikk strålebehandling med totaldose 50 Gy mot hele brystet etter brystbevarende kirurgi. Adjuvant medikamentell behandling ble gitt i henhold til nasjonale retningslinjer til 51 pasienter. Median alder ved diagnose var 59 år (spredning 34-82 år). Median tumorstørrelse var $12 \mathrm{~mm}$ (spredning $1-30 \mathrm{mml}$ og $86,5 \%$ av pasientene hadde NO sykdom. Etter en median oppfølgingstid på $96 \mathrm{md}$. (spredning 28-111 md.) har vi registrert tre tilbakefall i ipsilateralt bryst $1,4 \%$; $95 \% \mathrm{KI}$ $(0,5-4,4 \%))$. Beregnet brystkreftspesifikk overlevelse ved åtte år var $95 \%$ og totaloverlevelse $90 \%$.

Fortolkning. Våre resultater viser utmerket lokal sykdomskontroll etter brystbevarende kirurgi og strålebehandling med stråledose $50 \mathrm{~Gy}$ til hele brystet hos en gruppe kvinner med tidlig, lavrisiko brystkreft der bare om lag en firedel fikk adjuvant medikamentell behandling.
Ingvil Mjaaland

mjin@sus.no

Klinikk for blod-og kreftsykdommer

Stavanger universitetssjukehus

4608 Stavanger

\section{Ron M.P. Segers †}

Kjell Ivar Dybvik

Klinikk for blod-og kreftsykdommer

Ottar Bjerkeset

Ortopedisk kirurgisk avdeling

Stavanger universitetssjukehus

\section{Jan Terje Kvaløy}

Institutt for matematikk og naturvitenskap

Universitetet i Stavanger

og

Fag og foretaksutvikling

Stavanger universitetssjukehus

\section{Reino Heikkilä*}

Klinikk for blod-og kreftsykdommer

Stavanger universitetssjukehus

* Nåværende adresse:
Roche Norge

Oslo

Brystkreft er den hyppigste kreftformen blant kvinner i Norge. I 2007 ble det registrert 2761 nye tilfeller, og insidensen har i flere tiår vært økende. Tidlig diagnose og bedre behandling har vært assosiert med en reduksjon av sykdomsrelatert mortalitet, men brystkreft er fortsatt den tredje hyppigste årsaken til kreftrelatert død blant norske kvinner (1).

Ved konsensuskonferansen i regi av National Institutes of Health (NIH) i 1990 ble brystbevarende kirurgi vurdert som standardbehandling for en stor del av pasientene med brystkreft i tidlig stadium (2). Det er funnet lik overlevelse med denne tilnærmingen sammenliknet med mastektomi (3-5). Det er også vist at lokal strålebehandling etter kirurgi reduserer risiko for tilbakefall i operert (ipsilateralt) bryst (lokalt tilbakefall) med omkring $70 \%$ (6-9). Blant pasienter som ble behandlet frem til midten av 1990-årene er insidensen av lokalt tilbakefall funnet å være i størrelsesorden 4-7\% etter fem år, med en persisterende årlig risiko på ca. $0,5-1 \%$. For pasienter som har fått behandling de senere årene, er det rapportert en ytterligere reduksjon i den lokale tilbakefallsraten, ned til nivåer under $2 \%$ fem år etter behandling. Tidligere diagnose, bedre diagnostikk, kirurgi og stråleterapi og utvidede indikasjoner for adjuvant medikamentell behandling kan ha bidratt til dette (10-12).

Formålet med denne retrospektive studien var å kvalitetssikre at resultatene våre ved brystbevarende behandling, målt ved lokal tilbakefallsrate og overlevelse, var i samsvar med nyere internasjonale resultater. Selv om behandlingen ble gjennomført etter nasjonale retningslinjer, er en slik evaluering viktig fordi tekniske detaljer i behandlingen, ikke minst ved strålebehandling, er vanskelig å standardisere og kan bidra til betydelige variasjoner $\mathrm{i}$ behandlingsresultat mellom ulike institusjoner (13). Denne problemstillingen var særlig aktuell for oss fordi Stavanger universitetssjukehus fra 1999 var det første sykehuset utenom regionsykehus som ga moderne strålebehandling til kreftpasienter i Norge. En tidligere gjennomgang, med median oppfølgingstid på to år, viste ingen lokale tilbakefall (14). To år er i denne sammenhengen kort tid, og vi presenterer nå resultatene etter åtte års median oppfølgingstid.

\section{Materiale og metode}

Fra 14. juni 1999 til 8. mars 2002 ble alle pasienter henvist til oss for postoperativ strålebehandling etter brystbevarende kirurgi, fortløpende registrert, såfremt det etter gjeldende retningslinjer forelå indikasjon for strålebehandling. Av totalt 222 kvinner var 64 operert ved andre sykehus, og henvist til oss $\mathrm{i}$ forbindelse med strålebehandlingen. Alle pasientene fikk utført enten aksilledisseksjon (159 pasienter), vaktpostlymfeknutediagnostikkk (33 pasienter) eller begge deler (30 pasienter). Histologipreparater og bildediagnostikk for de 158 pasientene som var operert ved vårt sykehus, ble diskutert på ukentlige tverrfaglige møter.

\section{Strålebehandling}

Strålebehandling mot hele brystet ble gitt med motgående tangentielle felt med $6 \mathrm{MV}$ fotonstråling til totaldose $50 \mathrm{~Gy}$, fraksjonsdose 2 Gy. Tilleggsdose (boost) med 10 Gy

\section{Hovedbudskap}

- Brystbevarende behandling uten adjuvant medikamentell behandling gir svært lav lokal tilbakefallsrate hos pasienter med brystkreft i tidlig stadium

- Resultatene fra den første stråleterapiavdelingen utenfor regionsykehus i Norge er på nivå med resultater fra internasjonale undersøkelser 
(2 Gy fraksjoner) elektronstråling mot tumorområdet ble gitt til to pasienter. I Helseregion Vest var det på denne tiden ikke anbefalt å gi tilleggsdose mot tumorområdet, uansett pasientalder, under forutsetning av at tumor ble ansett for å være fritt fjernet. Feltinnstillingen ble gjort konvensjonelt ved simulator, feltstørrelse og apparatvinkel ble bestemt på grunnlag av palpasjon. Deretter ble det gjennomført en CT-basert, tredimensjonal doseberegning for alle pasientene. Målvolumet (CTV) ble tegnet inn av lege, og homogen dosefordeling i målvolumet tilstrebet ved hjelp av kiler og flerbladskollimator. Samtidig strålebehandling mot begge sider ble gitt til fire pasienter med bilateral brystkreft. Ved hjelp av et fotonfelt forfra ble strålebehandling mot periklavikulærområdet/aksillenivå III gitt til 13 pasienter som hadde tumorinfiltrasjon i aksillære lymfeknuter. For kvinner 55 år eller eldre anbefalte man i nasjonale retningslinjer den gang å bestråle lokoregionale lymfeknutestasjoner bare hvis det var påvist tumorinfiltrasjon i minst fire aksillære lymfeknuter. For kvinner under 55 år ble slik behandling anbefalt dersom det forelå minst én positiv lymfeknute i aksillen. Parasternale lymfeknuter ble ikke inkludert i målvolumet.

\section{Adjuvant medikamentell behandling}

Adjuvant medikamentell behandling i form av kjemoterapi og/eller endokrin behandling ble gitt $\mathrm{i}$ henhold til retningslinjer fra Norsk brystkreftgruppe. Kjemoterapi besto av seks FEC-kurer (5-FU $600 \mathrm{mg} / \mathrm{m}^{2}$, epirubicin 60 $\mathrm{mg} / \mathrm{m}^{2}$ og cyklofosfamid $600 \mathrm{mg} / \mathrm{m}^{2}$ ) gitt hver tredje uke, standard endokrin behandling var tamoksifen $20 \mathrm{mg}$ daglig i fem år. I tillegg deltok 18 pasienter i en placebokontrollert studie der man undersøkte effekt av aromatasehemmeren eksemestan på beintetthet og lipidnivå i plasma hos kvinner som etter gjeldende retningslinjer ikke var kandidater for adjuvant medikamentell behandling (15).

I tillegg til årlig bilateral mammografi ble pasientene de første ett til to årene fulgt opp med halvårlige, senere årlige, kliniske kontroller hos kirurg og senere hos allmennlege. Pasientene ble identifisert ved hjelp av diagnosekoder i verifikasjonssystemet $i$ stråleterapiavdelingen og ble fortløpende registrert. Det ble gjennomført manuell gjennomgang av journal. Informasjon om tilbakefall og overlevelse ble hentet ut fra journalnotater og epikriser fra andre sykehus og fra kontakt med primærleger for pasienter utenfor nedslagsområdet for vårt sykehus. Alle pasienter som fortsatt var i live ble tilskrevet og informert om studien. Innsamling av data ble avsluttet 31. august 2008. Studien er godkjent av Regional etisk komité Vest-Norge og av Norsk samfunnsvitenskapelig datatjeneste som et kvalitetssikringsprosjekt.

Statistiske metoder

Sannsynlighet (med konfidensintervall) for lokalt tilbakefall og overlevelseskurver (med konfidensintervaller) for brystkreftspesifikk overlevelse og totaloverlevelse (tid til død uavhengig av årsak) ble beregnet fra start av strålebehandling ved hjelp av Kaplan-Meiermetoden. De statistiske analysene ble utført ved hjelp av programpakken $R$, versjon 2.7.4 (16).

\section{Resultater}

I perioden mellom 14. juni 1999 og 8. mars 2002 gjennomgikk 222 pasienter med tidlig brystkreft strålebehandling mot hele brystet med totaldose 50 Gy etter brystbevarende kirurgi. Median oppfølgingstid var $96 \mathrm{md}$. (spredning 28-111 md.). Median pasientalder ved behandlingstidspunktet var 59 år (34-82 år). Kliniske og histopatologiske karakteristika gjengis i tabell 1 . Hos 151 pasienter $(68,6 \%)$ var tumor oppdaget ved screening. Median tumorstørrelse var 12 $\mathrm{mm}(1-30 \mathrm{~mm})$ og $201(90,5 \%)$ av pasientene hadde en T1-tumor $(\leq 20 \mathrm{~mm})$. Tumor var fjernet med mikroskopisk frie render hos alle pasienter, enten ved primær reseksjon (150 pasienter) eller etter reeksisjon (72 pasienter). Hos ni pasienter forelå det marginer mindre enn $5 \mathrm{~mm}$, hos fire av disse var den minste avstanden lokalisert mot hud eller muskulatur. For to andre pasienter var minste avstand til fritt vev ikke angitt. Hos de øvrige 211 pasientene var tumor omgitt av minst $5 \mathrm{~mm}$ normalt vev. Spredning til aksillære lymfeknuter forelå hos 30 pasienter $(13,5 \%)$.

Basert på nasjonale retningslinjer fikk 51 pasienter $(23 \%)$ adjuvant medikamentell behandling. Av disse gjennomgikk 13 kjemoterapi etterfulgt av endokrin behandling, ni pasienter fikk kun kjemoterapi og 29 fikk kun endokrin behandling. Når vi forutsetter at ni av 18 randomiserte pasienter fikk eksemestan i den placebokontrollert studien, må vi regne med at totalt 60 eller $27 \%$ av våre pasienter fikk adjuvant medikamentell behandling.

Tilbakefall i ipsilateralt bryst er registrert hos tre pasienter $(1,4 \% ; 95 \% \mathrm{KI}(0,5-4,4 \%))$ (fig 1). Alle disse tre var over 50 år ved diagnosetidspunktet, alle hadde positiv østrogenog/eller progesteronreseptorstatus, og tumor var mindre enn $21 \mathrm{~mm}$ hos alle. Det ble funnet tumorinfiltrasjon i aksillære lymfeknuter (to av 12) hos én av de tre pasientene og histologisk grad varierte fra en til tre. Tumor var fritt fjernet hos alle. Én av kvinnene ble behandlet med mastektomi og hadde ingen flere brystkreftrelaterte hendelser, og én døde av sin sykdom. Den tredje kvinnen er i live og residivfri etter brystbevarende operasjon for et intracystisk papillært karsinom. Vi har blant våre pasienter ikke registrert tilbakefall i lokoregionale lymfeknuter.

Frem til august 2008 har vi registrert 22 dødsfall. Av disse er ti relatert til brystkreft. Beregnet brystkreftspesifikk overlevelse ved åtte år er 95\% (95\% KI (92-98\%)) og totaloverlevelse er $90 \%$ (95\% KI (85-94\%)) (fig 2 og fig 3). Ny primær kreftsykdom er
Tabell 1 Karakteristikk av de 222 pasientene som inngikk i studien

Alder (år)

Median

Variasjonsbredde

$34-82$

$\leq 40$

$41-50$

$51-60$

$61-70$

$71-80$

$>80$

\section{Screeningoppdaget}

$\mathrm{Ja}$

$\mathrm{Nei}$

Hormonreseptorstatus - østrogen og/eller progesteron

Positiv

Negativ

Histologisk grad

Grad 1

Grad 2

Grad 3

Tumorstørrelse, $p T$-stadium

Median

$12 \mathrm{~mm}$

Variasjonsbredde

$1-30 \mathrm{~mm}$

pT1a og b $\leq 10 \mathrm{~mm}$

96

pT1c $>10 \leq 20 \mathrm{~mm}$

105

pT2 > $20 \mathrm{~mm}$

pT3

$p N$-status

$\mathrm{pNO}$

$\mathrm{pN} 1-2$

Histologi

Infiltrerende duktalt karsinom 189

Lobulært karsinom

Tubulært karsinom

Mucinøst adenokarsinom

Kribriformt karsinom

Papillært adenokarsinom

Lavt differensiert adenokarsinom

diagnostisert hos 18 pasienter; ni i kontralateralt bryst, de øvrige fordelt på: endometrium $(n=2)$, ovarier $(n=2)$, colon, rectum, lunge, kronisk lymfatisk leukemi og malignt melanom.

\section{Diskusjon}

Den lokale tilbakefallsraten etter brystbevarende kirurgi og strålebehandling, 1,4\% (95 \% KI $(0,5-4,4 \%))$ i vårt materiale etter åtte års observasjonstid, er i samme størrelsesorden som nyere internasjonale resultater. På grunn av ulikheter i pasientpopulasjoner og behandling er det imidlertid vanskelig å foreta presise sammenlikninger mellom studiene $(12,17,18)$. En rekke faktorer er kjent å kunne påvirke den lokale tilbake- 


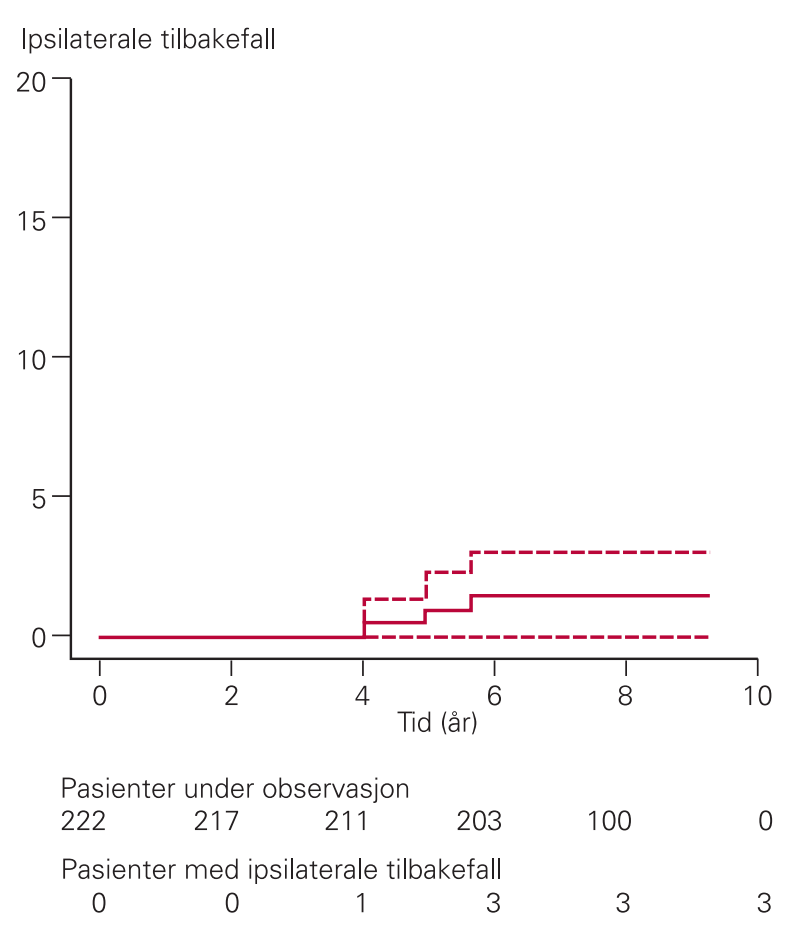

Figur 1 Kumulativ insidens av lokalt tilbakefall i ipsilateralt bryst etter 50 Gy bestråling av hele brystet, åtte års median oppfølgingstid (heltrukket linje), 95 \% konfidensintervall (stiplede linjer)

fallsraten, enten knyttet til pasientseleksjon (alder, T- og N-stadium) eller til behandling (fri reseksjonsrand, stråledose og fraksjonering, tillegg av medikamentell adjuvant behandling) (17). For å forklare bedringen i behandlingsresultatene i løpet av de siste tiårene er også bedre diagnostikk, kirurgisk og stråleterapeutisk teknikk og multidisiplinær behandling basert på gode retningslinjer trukket frem $(10,11)$.
Tabell 2 viser en forenklet oversikt over nyere studier der den lokale tilbakefallsraten etter brystbevarende behandling med kirurgi og ekstern strålebehandling er rapportert. Oversikten begrenser seg til studier der den lokale tilbakefallsraten var i samme størrelsesorden som $i$ vårt materiale, $<3 \%$ etter minst fem års observasjonstid. I tabellen er studiene rangert etter andel pasienter som var under 60 år ved behandlingsstart (10-12, 19-23). Det er dokumentert, bl.a i en metaanalyse fra en europeisk gruppe (EBCTCG), at lokal tilbakefallsrisiko er inverst relatert til alder, uavhengig av hvilken type strålebehandling som gis (6). Tabellen viser tall som er i samsvar med dette, de aller laveste femårsratene, $<1 \%$, er observert $\mathrm{i}$ studier der andelen pasienter under 60 år var lav.

Med unntak for vår studie er de lave tilbakefallsratene oppnådd ved samtidig bruk av adjuvant medikamentell behandling hos flertallet av pasientene. I Fisher og medarbeideres studie (NSABP-B21) reduserte kombinasjonen stråleterapi og tamoksifen raten til en tredel sammenliknet med stråleterapi alene (20).

Tabellen illustrerer også at stråledose kan ha betydning for tilbakefallsraten. Det er fra før vist $\mathrm{i}$ en europeisk randomisert studie (EORTC 22881) at tilleggsbehandling (boost) med ioniserende stråling mot et begrenset område etter ordinær behandling av hele brystkjertelen, reduserer risiko for lokalt tilbakefall med i størrelsesorden $40 \%$ (18). Som tabellen viser, ble boostbehandling brukt



Pasienter under observasjon

$\begin{array}{cccccc}222 & 217 & 212 & 206 & 103 & 0 \\ \text { Pasienter } & \text { med brystkreftspesifikk } & \text { død } & & \\ 0 & 4 & 6 & 8 & 9 & 10\end{array}$

Figur 2 Brystkreftspesifikk overlevelse etter 50 Gy bestråling av hele brystet, åtte års median oppfølgingstid (heltrukket linje), 95 \% konfidensintervall (stiplede linjer)

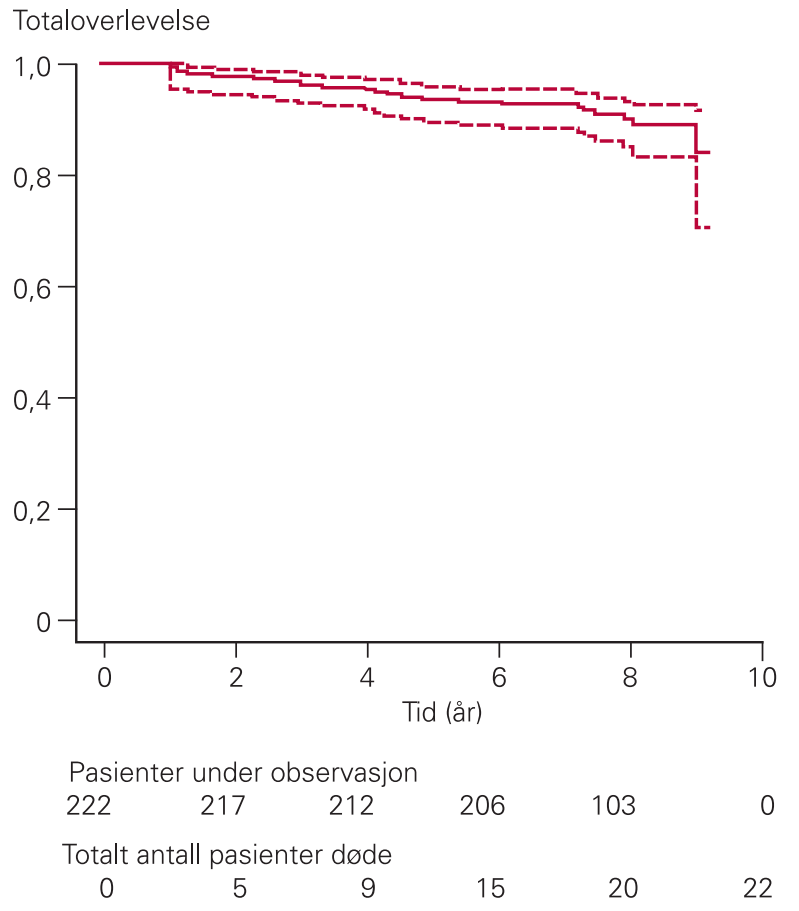

Figur 3 Totaloverlevelse etter 50 Gy bestråling av hele brystet, åtte års median oppfølgingstid (heltrukket linje), $95 \%$ konfidensintervall (stiplede linjer) 
i betydelig utstrekning, utenom i vår studie og i NSABP-B21-studien. NSABP-B21-studien skiller seg imidlertid ut fra de øvrige ved at den så å si utelukkende rekrutterte kvinner med svulststørrelse under $1 \mathrm{~cm}$. Så vel tumorstørrelse som tilstedeværelse av aksillære lymfeknutemetastaser er vist å påvirke lokal tilbakefallsrisiko (6).

På bakgrunn av fordelingen av risikofaktorene som er diskutert ovenfor, er den registrerte lokale tilbakefallsraten blant pasientene $\mathrm{i}$ vårt materiale overraskende lav. Med et såvidt lavt antall hendelser er det imidlertid stor statistisk usikkerhet om den «sanne» verdien, som delvis er beskrevet av det beregnede konfidensintervallet. Måten pasientene har vært fulgt opp i denne retrospektive studien, gjør også at man ikke kan utelukke en liten usikkerhet knyttet til rapporteringen av tilbakefall. Dette gjelder særlig for de om lag 60 pasientene som var operert ved annet sykehus, og som ved et eventuelt behandlingstrengende tilbakefall sannsynligvis ikke ville ha fătt behandling i Stavanger. Vi har for disse pasientene basert oss på innhentet informasjon fra primærlegen og ikke uoppfordret etterspurt informasjon fra sykehus på pasientens hjemsted.

Det er også mulig at det reelle kravet til mikroskopisk fri rand hos oss kan ha vært større enn i de andre studiene som er referert i tabellen. I studiene i tabell 2 var mikroskopisk fri rand et definert krav. I noen av studiene er dette definert som $\geq 1 \mathrm{~mm}$ fri rand, i andre er dette ikke spesifisert. Også i vårt materiale var kravet mikroskopisk fri rand, men $95 \%$ av pasientene hadde minst $5 \mathrm{~mm}$ fri margin før strålebehandling. Det er imidlertid usikkert hvilken betydning dette kan ha hatt for utfallet $(7,17,24)$. Utvelgelse av pasienter for brystbevarende kirurgi foregikk ved vårt sykehus etter de samme kriterier som i landet for øvrig. Andelen brystbevarende operasjoner i relasjon til totalt antall opererte var i det aktuelle tidsrommet noe over $40 \%$ og lå på nivå med det som ble rapportert fra andre sykehus i Norge på den tiden brystkreftscreening ble innført (14, 25). Etter mange år med screening er denne andelen i dag i overkant av $50 \%$ ved vårt sykehus (upubliserte data).

Samlet sett støtter våre resultater erfaringene fra andre institusjoner som over tid har opplevd bedring i behandlingsresultatene, blant annet ved å vektlegge en multidisiplinær behandlingstilnærming og behandling etter omforente retningslinjer (10, 11). Studien bekrefter også at behandling etter de nasjonale retningslinjene gjør det mulig å oppnå meget god lokal kontroll hos lavrisikopasienter, uten utstrakt bruk av adjuvant medikamentell behandling og uten å gi høyere stråledose enn 50 Gy i 25 fraksjoner. Det er uavklart om CT-basert, tredimensjonal doseberegning for å oppnå homogen dosefordeling, slik det er anvendt $\mathrm{i}$ vår studie, også kan ha bidratt til svært god lokal sykdomskontroll hos våre pasienter.

Metaanalysen fra EBCTCG tyder på at lav lokal tilbakefallsrate også er av betydning for brystkreftrelatert overlevelse og konkluderer med at ved å forhindre fire lokale tilbakefall vil man kunne unngå ett brystkreftrelatert dødsfall etter 15 år (6). Nyere undersøkelser tyder på at denne sammenhengen er tydeligst i pasientpopulasjoner med lav risiko for tilbakefall og av mindre betydning for pasienter med en ugunstig prognose i utgangspunktet (26). Det er derfor rimelig å anta at god lokal behandling vil bidra til å redusere risiko for senere brystkreftrelatert død i pasientpopulasjoner med gunstig risikoprofil. Vi har hittil registrert totalt 22 dødsfall, derav ti brystkreftrelaterte. Siden over halvparten av brystkreftrelaterte dødsfall forventes å komme etter de første fem årene, er åtte års observasjonstid ikke tilstrekkelig for å få et fullstendig bilde av den brystkreftrelaterte dødeligheten i vår pasientpopulasjon.

\section{Konklusjon}

Våre resultater viser et lavt antall lokale tilbakefall etter brystbevarende kirurgi og strålebehandling til stråledose 50 Gy med CTbasert, tredimensjonal doseberegning $\mathrm{i}$ en lavrisikopopulasjon der bare om lag en firedel av pasientene fikk adjuvant medikamentell behandling.

\section{Oppgitte interessekonflikter: Ingen}

\section{Litteratur}

1. Kreftregisteret. Kreft i Norge 2007 - insidens overlevelse og prevalens i Norge 2008. Oslo: Kreftregisteret, 2008.

2. NIH consensus conference. Treatment of earlystage breast cancer. JAMA 1991; 265: 391-5.

Tabell 2 Oversikt over studier med rapportert femårs lokal tilbakefallsrate $<3 \%$ etter brystbevarende kirurgi og postoperativ ekstern strålebehandling

\begin{tabular}{|c|c|c|c|c|c|c|c|c|c|c|}
\hline & Antall & < 60 år (\%) & T1a+b (\%) & T1 (\%) & N0 (\%) & $\begin{array}{c}\text { Stråle- } \\
\text { dose } \\
\text { (Gy) }\end{array}$ & Boost $^{2}(\%)$ & $\begin{array}{c}\text { Adjuvant } \\
\text { behandling } \\
(\%)\end{array}$ & LRR $^{4} 5$ år (\%) & $\operatorname{LRR}^{4} 8$ år (\%) \\
\hline Mjaaland og medarbeidere & 222 & 62 & 44 & 91 & 87 & $50 / 2$ & 1 & 27 & 0,9 & 1,4 \\
\hline $\begin{array}{l}\text { Nguyen og medarbeidere } \\
2008 \text { (12) }\end{array}$ & 793 & 60 & 36 & 80 & 71 & $50 / 2$ & 50 & 90 & 1,8 & - \\
\hline \multirow{2}{*}{$\begin{array}{l}\text { Bentzen og medarbeidere } \\
2008 \text { (19) }\end{array}$} & 1110 & 61 & 14 & 64 & 75 & $50 / 2$ & 41 & 97 & 3,3 & \multirow{2}{*}{ - } \\
\hline & 1105 & 59 & 15 & 64 & 72 & $40 / 2,7$ & 44 & 96 & 2,0 & \\
\hline \multirow{2}{*}{$\begin{array}{l}\text { Fisher og medarbeidere } \\
2002(20)\end{array}$} & 334 & 52 & 99 & 100 & 100 & $50 / 2$ & 25 & 100 & & 2,8 \\
\hline & 334 & 46 & 98 & 100 & 100 & $50 / 2$ & 25 & 0 & & 9,3 \\
\hline $\begin{array}{l}\text { Pass og medarbeidere } 2004 \\
\text { (10) }\end{array}$ & $N R^{5}$ & 42 & $\mathrm{NR}^{5}$ & 74 & 78 & $46 / 2$ & 100 & 70 & 1 & - \\
\hline $\begin{array}{l}\text { Cabioglu og medarbeidere } \\
2005 \text { (11) }\end{array}$ & 383 & 37 & $\mathrm{NR}^{5}$ & 59 & 79 & $50 / 2$ & 60 & 50 & 1,3 & - \\
\hline $\begin{array}{l}\text { Potter og medarbeidere } \\
2007 \text { (21) }\end{array}$ & 414 & 30 & 35 & 90 & 100 & $50 / 2$ & 70 & 100 & 0,4 & - \\
\hline $\begin{array}{l}\text { Fyles og medarbeidere } 2004 \\
\text { (22) }\end{array}$ & 386 & 25 & 33 & 83 & 100 & $40 / 2,5$ & 100 & 100 & 0,6 & 3,5 \\
\hline $\begin{array}{l}\text { Hughes og medarbeidere } \\
2004 \text { (23) }\end{array}$ & 317 & 0 & $\mathrm{NR}^{5}$ & 98 & 100 & $45 / 1,8$ & 100 & 100 & 1 & - \\
\hline
\end{tabular}

1 Totaldose/fraksjonsdose ved ekstern strålebehandling mot hele brystet

${ }^{2}$ Andel pasienter som fikk tilleggsdose (boost) mot et mindre volum ved strålebehandling

${ }^{3}$ Andel pasienter som fikk adjuvant medikamentell behandling (hormon- og/eller kjemoterapi)

${ }^{4}$ Lokal tilbakefallsrate etter 5 (hhv. 8) år

5 Ikke angitt 
3. Fisher B, Anderson S, Bryant J et al. Twenty-year follow-up of a randomized trial comparing total mastectomy, lumpectomy, and lumpectomy plus irradiation for the treatment of invasive breast cancer. N Engl J Med 2002; 347: 1233-41.

4. Veronesi U, Cascinelli N, Mariani L et al. Twentyyear follow-up of a randomized study comparing breast-conserving surgery with radical mastectomy for early breast cancer. N Engl J Med 2002; 347: 1227-32

5. Blichert-Toft M, Nielsen M, During M et al. Longterm results of breast conserving surgery vs. mastectomy for early stage invasive breast cancer 20-year follow-up of the Danish randomized DBCG-82TM protocol. Acta Oncol 2008; 47: $672-81$

6. Clarke M, Collins R, Darby $S$ et al. Effects of radiotherapy and of differences in the extent of surgery for early breast cancer on local recurrence and 15-year survival: an overview of the randomised trials. Lancet 2005; 366: 2087-106.

7. Liljegren $G$, Holmberg L, Bergh J et al. 10-Year results after sector resection with or without postoperative radiotherapy for stage I breast cancer: a randomized trial. J Clin Oncol 1999; 17: 2326-33.

8. Forrest AP, Stewart HJ, Everington D et al. Randomised controlled trial of conservation therapy for breast cancer: 6-year analysis of the Scottish trial. Scottish Cancer Trials Breast Group. Lancet 1996; 348: 708-13

9. Bartelink H, Horiot JC, Poortmans P et al. Recurrence rates after treatment of breast cancer with standard radiotherapy with or without additional radiation. N Engl J Med 2001; 345: 1378-87.

10. Pass H, Vicini FA, Kestin LL et al. Changes in management techniques and patterns of disease recurrence over time in patients with breast carcinoma treated with breast-conserving therapy at a single institution. Cancer 2004; 101: 713-20.
11. Cabioglu N, Hunt KK, Buchholz TA et al. Improving local control with breast-conserving therapy: a 27-year single-institution experience. Cancer 2005; 104: $20-9$.

12. Nguyen PL, Taghian AG, Katz MS et al. Breast cancer subtype approximated by estrogen receptor, progesterone receptor, and HER-2 is associated with local and distant recurrence after breast-conserving therapy. J Clin Oncol 2008; 26: 2373-8.

13. van Dongen JA, Voogd AC, Fentiman IS et al. Longterm results of a randomized trial comparing breast-conserving therapy with mastectomy: European Organization for Research and Treatment of Cancer 10801 Trial. J Natl Cancer Inst 2000; 92: 1143-50.

14. Mjaaland I, Dybvik KI, Heikkil R et al. Strålebehandling etter brystbevarende kirurgi. Tidsskr Nor Lægeforen 2003; 123: 1683-4.

15. Lonning PE, Geisler J, Krag LE et al. Effects of exemestane administered for 2 years versus placebo on bone mineral density, bone biomarkers, and plasma lipids in patients with surgically resected early breast cancer. J Clin Oncol 2005; 23: 5126-37.

16. The R Project for Statistical Computing. (www.r-project.org) (6.1.2010).

17. Mannino M, Yarnold JR. Local relapse rates are falling after breast conserving surgery and systemic therapy for early breast cancer: can radiotherapy ever be safely withheld? Radiother Oncol 2009; 90: 14-22.

18. Bartelink H, Horiot JC, Poortmans PM et al. Impact of a higher radiation dose on local control and survival in breast-conserving therapy of early breast cancer: 10-year results of the randomized boost versus no boost EORTC 22881-10882 trial. J Clin Oncol 2007; 25: 3259-65.

19. Bentzen SM, Agrawal RK, Aird EG et al. The UK Standardisation of Breast Radiotherapy (START)
Trial B of radiotherapy hypofractionation for treatment of early breast cancer: a randomised trial. Lancet 2008; 371: 1098-107.

20. Fisher B, Bryant J, Dignam JJ et al. Tamoxifen, radiation therapy, or both for prevention of ipsilateral breast tumor recurrence after lumpectomy in women with invasive breast cancers of one centimeter or less. J Clin Oncol 2002; 20: 4141-9.

21. Potter R, Gnant M, Kwasny W et al. Lumpectomy plus tamoxifen or anastrozole with or without whole breast irradiation in women with favorable early breast cancer. Int J Radiat Oncol Biol Phys 2007; 68: 334-40.

22. Fyles AW, McCready DR, Manchul LA et al. Tamoxifen with or without breast irradiation in women 50 years of age or older with early breast cancer. N Engl J Med 2004; 351: 963-70.

23. Hughes KS, Schnaper LA, Berry D et al. Lumpectomy plus tamoxifen with or without irradiation in women 70 years of age or older with early breast cancer. N Engl J Med 2004; 351: $971-7$.

24. Antonini N, Jones H, Horiot JC et al. Effect of age and radiation dose on local control after breast conserving treatment: EORTC trial 22881-10882. Radiother Oncol 2007; 82: 265-71.

25. Kåresen R. Brystkreft. Tidsskr Nor Lægeforen 1997: 117: 3763-4.

26. Kyndi M, Sorensen FB, Knudsen $\mathrm{H}$ et al. Estrogen receptor, progesterone receptor, HER-2, and response to postmastectomy radiotherapy in highrisk breast cancer: the Danish Breast Cancer Cooperative Group. J Clin Oncol 2008; 26 : $1419-26$.

Manuskriptet ble mottatt 3.4. 2009 og godkjent 17.12. 2009. Medisinsk redaktør Åslaug Helland. 